\title{
Assessment of Application Timing of Bacillus spp. to Suppress Pre- and Postharvest Diseases of Apple
}

Anissa M. Poleatewich, Department of Plant Pathology, Penn State University, University Park, PA 16802; Henry K. Ngugi, Penn State University Fruit Research and Extension Center, Biglerville, PA 17307; and Paul A. Backman, Department of Plant Pathology, Penn State University, University Park

\begin{abstract}
Poleatewich, A. M., Ngugi, H. K., and Backman, P. A. 2012. Assessment of application timing of Bacillus spp. suppress pre- and postharvest diseases of apple. Plant Dis. 96:211-220.

Four isolates of Bacillus spp. were tested in a 2-year field study for biological control of pre- and postharvest diseases of apple. For the preharvest test, bacteria were applied to 'Golden Delicious' and 'Rome Beauty' trees in May or May and June. Foliar apple scab severity was assessed weekly. After harvest, fruit were wounded and then either left untreated or given a postharvest application of the bacteria. Wounded fruit were then inoculated with the bitter rot pathogen and lesion size was measured over 8 days. Bacillus megaterium isolate A3-6, B. mycoides isolate A1-1, and B. cereus isolate FLS-5 applied in May or May and June significantly reduced fruit and foliar apple scab severity

in both years. A postharvest application of the bacteria (alone or in combination with a preharvest application) resulted in the greatest suppression of bitter rot on both cultivars $(P<0.04)$. The May + June + postharvest application of isolate A3-6 resulted in the greatest suppression of bitter rot, with an average of 45 and $95 \%$ reduction in lesion size compared with nontreated controls on 'Golden Delicious' and 'Rome Beauty' fruit, respectively. Results from this study indicate that preharvest applications of the bacteria were able to reduce foliar and fruit scab and an additional postharvest application was effective in reducing bitter rot severity.
\end{abstract}

Dependence on pesticides with a site-specific mode of action for plant disease management has prompted an interest in organic and sustainable agriculture. Specific concerns include pesticide residues in food, groundwater contamination, and non-target effects of broad-spectrum chemicals (27). As a result, there is an increasing consumer-driven demand for the development of biologically based alternatives to chemical pest-control products. The continued dependence on chemical pesticides has also resulted in the development of pesticide resistance among many insect, weed, and pathogen populations and a subsequent reduction in pesticide efficacy. Alternatives are needed to supplement existing disease-control strategies while achieving acceptable levels of control.

Considerable attention has focused on the potential use of biological control for postharvest disease management of fruits and vegetables $(12,28,33)$. However, commercialization and use of most postharvest biocontrol products remain limited due to inconsistency in their efficacy, low levels of control when used as standalone products, and apparent inability to control previously established latent infections (7). Infection by postharvest pathogens frequently occurs either during the growing season or during harvest, when mechanical injury commonly occurs, providing entry points for the pathogens. Although appearing healthy at harvest, many fruit harbor quiescent or latent infections that, over time, produce symptoms in storage as ripening occurs and host defenses weaken (8). Many biological control products registered for postharvest disease control are applied after harvest, when infection by

\section{Corresponding author: P. A. Backman, E-mail: pab24@psu.edu}

Current address of A. M. Poleatewich: Vineland Research \& Innovation Center, P.O. Box 4000 Vineland Station, ON, Canada; E-mail: Anissa Poleatewich@ vinelandresearch.com

\footnotetext{
* The $\boldsymbol{e}$-Xtra logo stands for "electronic extra" and indicates that Figure 2 appears in color online.
}

Accepted for publication 29 August 2011.

http://dx.doi.org/10.1094/PDIS-05-11-0383

(C) 2012 The American Phytopathological Society the pathogen may have already occurred. In a recent review article, Janisiewicz (11) stated that the main challenge for the next generation of postharvest biocontrol products is control of latent infections.

Successful disease control with a biological control agent (BCA) in both the field and postharvest depends on the appropriate application of the BCA in time and space (5). Research on postharvest disease management has typically focused on application of BCAs after harvest. Application after harvest, however, may be too late for the BCAs to effectively compete with decay pathogens already established on or in fruit tissues in the field. Furthermore, where the mode of action is the induction of active host defense mechanisms, BCAs applied after harvest may not be as effective as those applied while the fruit are still attached to the tree (4). Application of BCAs prior to harvest could allow their establishment on or in leaves and fruit in advance of pathogen arrival. In addition to postharvest protection, application of BCAs with broad antifungal activity (perhaps capable of inducing host defenses) during the growing season may confer the additional benefits of suppression of foliar diseases.

Some successes have been reported using preharvest field applications of biocontrol agents on apple and pear to control postharvest disease $(1,18,20)$. Nunes et al. (24) found that a 50:50 mixture of Candida sake CPA-1 and Pseudomonas syringae CPA-5 applied 2 days before harvest reduced blue mold (Penicillium expansum) incidence by $56 \%$ on apple and $90 \%$ on pear. Leibinger et al. (20) reported a significant suppression of storage rots, comparable with that provided by the sulfamide fungicide Euparen, using a mixture of Aureobasidium pullulans and Rhodotorula glutinis applied approximately 4 weeks and 2 weeks before harvest. Although preharvest applications of these BCAs resulted in disease suppression, experiments comparing pre- versus postharvest applications were not reported. In one of the few studies directly comparing combinations of pre- and postharvest BCA applications, Teixido et al. (31) reported a 50\% reduction in incidence and an $80 \%$ reduction in diameter of lesions on apple caused by $P$. expansum when treated with a postharvest application of $C$. sake. However, no additional advantages were reported when apples were treated with the BCA both pre- and postharvest.

As briefly reviewed here, a large majority of the postharvest biocontrol research reported in the literature has focused on applica- 
tion of BCAs after harvest. There are a limited number of studies on preharvest application strategies. Furthermore, research on preharvest application of BCAs has focused on applications made within 2 days to 2 weeks before harvest. There have not been reports of the effects of early or mid-season applications of BCAs on preharvest and postharvest disease incidence or severity on pome fruit. Given the available information, the question still remains: when is the best time for BCA applications for postharvest disease control? Experiments directly comparing levels of postharvest disease suppression by pre- and postharvest-applied BCAs are necessary to answer this question.

Research on biocontrol of postharvest diseases has also primarily focused on yeasts and gram-negative bacteria $(3,10,24,25,34)$. However, many organisms, while successful in research trials, are difficult to formulate and never reach the marketplace (9). However, the use of endospore-forming bacteria offers an advantage over some yeasts and gram-negative bacteria which are sensitive to environmental extremes and have a shorter shelf life as formulated products. Some gram-positive bacteria such as Bacillus and Streptomyces spp. produce spores resistant to heat and desiccation that can easily be formulated as a dry product and can be coapplied with pesticides (9). The overall goal of this study was to develop biocontrol agents for management of important diseases of apple in organic production. The specific objectives were to (i) investigate the potential for biocontrol of several apple diseases using endospore-forming bacteria collected from apple and (ii) evaluate application strategies of these organisms to optimize suppression of both pre- and postharvest diseases of apple.

\section{Materials and Methods}

Collection and screening of the biocontrol isolates. Healthy apple leaves and fruit were collected from three apple orchards maintained under a standard fungicide, a "reduced resistance risk" fungicide program, or a certified organic program at the Penn State Fruit Research and Extension Center (FREC) located in Biglerville, PA, and from three abandoned orchards (two orchards unmanaged for 1 year and one orchard unmanaged for 5 years) in Adam's County, PA during September 2006 and June 2007. For isolation of bacterial BCAs, two leaves per sample were placed in sterile 101-by-152-mm stomacher filter bags (Secure-T 80; Labplas, Sainte-Julie, Quebec, Canada) with $10 \mathrm{ml}$ of $0.1 \mathrm{M}$ potassium phosphate buffer ( $\mathrm{pH}$ 7.0) and agitated at 7 strokes/s for $30 \mathrm{~s}$ in a stomacher blender (Bagmixer 100 MiniMix; Intersciences, St. Nom, France). The leaf tissue was further triturated using a pestle. The suspension $(50 \mu \mathrm{l})$ was plated on tryptic soy agar (TSA; Difco, Franklin Lakes, NJ). To select for endospore-forming bacteria, three 1-ml aliquots of the agitated solution were pipetted into mi-
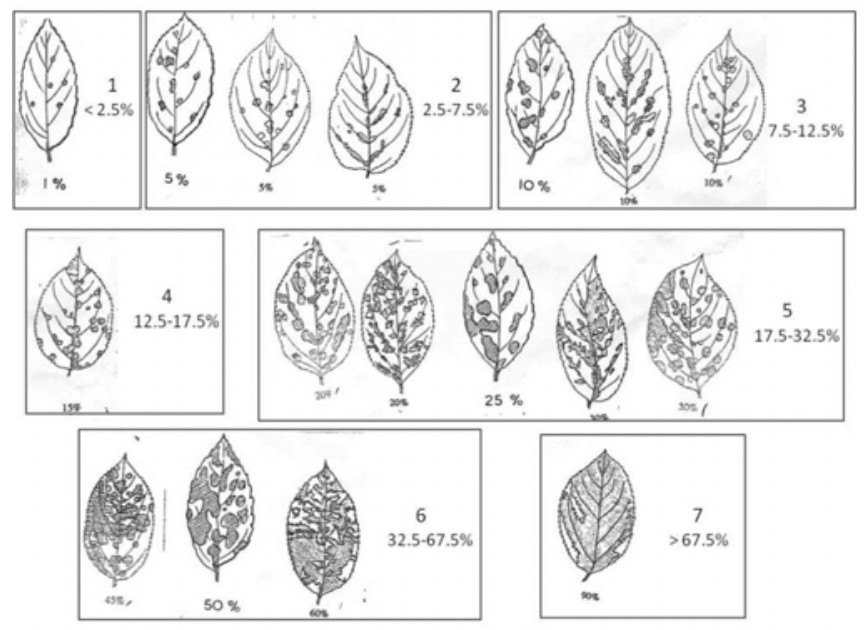

Fig. 1. Foliar apple scab disease rating scale used to estimate the percent leaf area with apple scab symptoms in field experiments. Visual diagrams were adapted from Tehon and Stout (32) and Croxall et al. (6) as reprinted by MacHardy (23). cro-centrifuge tubes and heat treated for $15 \mathrm{~min}$ at $75^{\circ} \mathrm{C}$ in a water bath. The heated suspensions were plated on TSA as before and incubated for $48 \mathrm{~h}$, and individual colonies were transferred onto fresh TSA plates.

The endospore-forming bacteria were then screened for the ability to hydrolyze chitin using a conventional plate method. Colloidal chitin was prepared using the method of Kokalis-Burelle (13). Bacterial isolates were streaked onto $0.4 \%$ colloidal chitin nutrient agar and isolates that produced a clearing zone were selected for further evaluation. In preliminary disease-suppression studies, the isolates that tested positive for endospore formation and chitinase production were evaluated for the ability to reduce the preharvest diseases apple scab (Venturia inaequalis) and fire blight (Erwinia amylovora) (data not shown). Six-week-old 'Golden Delicious' seedlings were used in growth-chamber studies to screen isolates for the ability to suppress apple scab symptoms. Seven days after spray inoculating leaves with the biocontrol bacteria, a conidial suspension $\left(3.0 \times 10^{4}\right.$ conidia/ml $)$ of $V$. inaequalis was prepared (26) and sprayed on leaves. The seedlings were transferred back to the growth chamber, maintained for 14 days, and evaluated for apple scab symptoms. Following growth-chamber studies, isolates were further screened for suppression of apple scab symptoms on mature trees. In both growth-chamber and preliminary field studies, apple scab severity was evaluated using a visual rating scale (Fig. 1). Isolates were also screened for suppression of fire blight symptoms in the greenhouse (19) on 'Golden Delicious' and 'Gala' trees grafted onto M26 rootstock planted in 11-liter pots. Isolates were also evaluated for the ability to reduce severity of the postharvest diseases bitter rot (Colletotrichum acutatum) and blue mold ( $P$. expansum) using the methods described below (data not shown). Following these preliminary screens, four isolates were selected for field experimentation.

Preparation of the biocontrol isolates. The four isolates tested included Bacillus mycoides isolate A1-1, B. megaterium isolate A3-6, B. cereus isolate FLS-5, and B. cereus isolate A3-F1. Bacterial stock solutions were prepared by growing bacterial isolates in $500 \mathrm{ml}$ of sterile tryptic soy broth in 2,800-ml Fernbach flasks. The flasks were incubated for 7 days at $28^{\circ} \mathrm{C}$ and $120 \mathrm{rpm}$ on a rotary incubator shaker (model M1024; New Brunswick Scientific, Edison, NJ). Bacterial cells were harvested by centrifugation at 6,000 rpm for $15 \mathrm{~min}$ at $4^{\circ} \mathrm{C}$ using a Sorvall RC5C Plus centrifuge (Thermo Scientific, Waltham, MA). The supernatant was discarded and the bacterial pellets were resuspended in $0.1 \mathrm{M}$ potassium phosphate buffer (PPB).

Field site. All field experiments were carried out at the Penn State University FREC in Biglerville, PA on mature 'Golden Delicious' and 'Rome Beauty' grafted on M.26 rootstock spaced at 10.7 by 3 by $2.4 \mathrm{~m}$. Maintenance programs for insect pests were applied with an airblast sprayer with applications as needed in all orchards following commercial production practices. Environmental conditions were recorded with electronic monitoring systems (Campbell Scientific, Logan, UT and Spectrum Weather Systems, East Plainfield, IL). Apple scab infection periods were determined using the modified Mill's table (22).

Evaluation of bacterial isolates for control of apple scab. Experiments were conducted in 2008 and 2009 to evaluate the timing of bacterial applications on suppression of preharvest (apple scab) and postharvest (bitter rot) diseases. Both cultivars received a dormant copper spray (3.18 kg of Kocide 3000; DuPont, Wilmington, DE) but did not receive any other fungicide or antibiotic treatment during the 2008 season. High scab pressure from this low-input program (dormant copper only) used in 2008 led to a limited number of clean fruit available for the postharvest phase of the experiment. Therefore, trees in the 2009 experiment received $3.18 \mathrm{~kg}$ of copper hydroxide (Kocide 3000) spray at half-inch green (10 April) and $2.3 \mathrm{~kg}$ of sulfur (MicroSulf WP; Nufarm Inc., Burr Ridge, IL) $+1.5 \%$ lime sulfur at 14-day intervals from first cover (22 May) to fifth cover ( 8 July) in 2009. The copper and sulfur treatments were applied with a boom sprayer at 400 psi, which delivered 935 liters/ha. The preharvest phase of the 2008 experiment consisted of 
a four-by-two-by-three factorial with four bacterial isolates (A1-1, A3-6, FLS-5, and A3-F1), two cultivars, and three timings of bacterial application. The 2009 experiment consisted of a three-bytwo-by-three factorial with three isolates (A1-1, A3-6, and FLS-5), two cultivars, and three timings of bacterial application. Branches were tagged and used for preharvest applications of bacterial isolates and as a source of fruit for postharvest applications. Three timings of bacterial application were evaluated: (i) one application in May, (ii) an application in May followed by an application in June, or (iii) a no-bacterial-application control. At the time of bacterial inoculation (in May and June), the last fully expanded leaf of two shoots per branch were marked with tape.

In 2008, each bacterial isolate was applied to branches on each of two replicate trees of each cultivar. Bacteria were applied to runoff using 1-liter handheld spray bottles on 10 May (May and May + June treatments) and 18 June (May + June treatment). Bacterial stock solutions were diluted for a final concentration of approximately $5.0 \times 10^{6} \mathrm{CFU} / \mathrm{ml}$ and $0.1 \%$ (vol/vol) Silwet L-77 (GE Silicones, Tarrytown, NY) was added immediately before application. Individual trees were inoculated with a single bacterial isolate and each of the bacterial treatments were applied to 4 replicate branches/tree (16 branches/treatment). At the time of application, branches designated as nontreated or as postharvest application were covered using 189-liter plastic bags to avoid contamination, and the bags were removed immediately after all treatments had been applied.

In 2009, each of the three isolates tested was applied to branches of four replicate trees of each cultivar. Bacteria were applied using a hand-pumped 11-liter Solo backpack sprayer (Solo, Newport News, VA) on 7 May (for May and May + June treatments) and 19 June (for May + June treatment). Bacterial stock solutions were diluted and applied as in 2008. Individual trees were spray inoculated with a single bacterial isolate at each of the two application timings (May or May + June) which were allocated to 4 branches/tree for a total of 8 sprayed branches/tree, with 32 branches/cultivar and 64 branches total/bacterial isolate. Bags were not used to protect untreated branches as described in 2008 because controls were located on separate trees in the 2009 experiment.

Foliar colonization of sprayed 'Golden Delicious' and 'Rome Beauty' trees was assessed 1 week and 7 weeks after the initial application of the bacteria in May. For each cultivar, two sprayed leaves were collected from each of two shoots from two replicate trees. Leaves were bagged and stored at 4 to $10^{\circ} \mathrm{C}$. The next day, two $4.2-\mathrm{cm}^{2}$ plugs were excised from the two leaves and placed in a 101-by-152-mm stomacher filter bag (Secure-T 80; Labplas) with $5 \mathrm{ml}$ of $0.1 \mathrm{M}$ PPB and agitated at 7 strokes/s for $30 \mathrm{~s}$ in a stomacher blender (Bagmixer 100 Minimix; Intersciences). The supernatant $(50 \mu \mathrm{l})$ was plated in duplicate on yeast extract dextrose agar using a spiral plater (Autoplate 4000; Spiral Biotech Inc., Norwood, MA). All plates were incubated for $24 \mathrm{~h}$ at room temperature and enumerated using a Spiral Biotech counting grid following the manufacturer's instructions. The minimum detectable population for this methodology was $\log _{10} 1.8 \mathrm{CFU} / \mathrm{cm}^{2}$. Bacteria were identified based on colony morphology, heat stability, and comparison with bacteria recovered from nontreated leaves.

Starting in May (2008 and 2009), the severity of apple scab disease was assessed weekly until terminal bud phonological stage was reached and new susceptible tissue was no longer available. Disease assessments were taken on leaves (equal to or younger

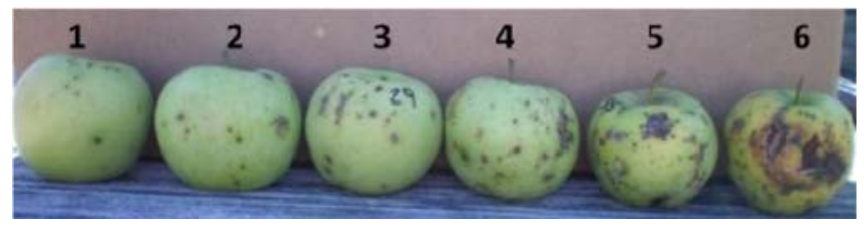

Fig. 2. Diagram for assessment of apple scab severity on fruit. Each fruit was assigned a value corresponding to the picture it most clearly resembled. Fruit lacking visible lesions were assigned a 0 . than the tagged leaf) of 2 shoots/branch on all Golden Delicious and Rome Beauty trees (32 shoots/treatment in 2008 and 64 shoots/treatment in 2009). To evaluate apple scab severity, percent leaf area scabbed was estimated on all leaves on two shoots per branch using a seven-point rating scale where $0=$ no visible symptoms and $1=<2,2=2$ to $7,3=7$ to $15,4=15$ to $25,5=25$ to 40 , $6=40$ to 60 , and $7=>60 \%$. Visual diagrams adapted from Tehon and Stout (30) and Croxall et al. (6) as reprinted by MacHardy (21) were used to classify each leaf to a "scale class" corresponding to the diagram it most closely resembled (Fig. 1). Midpoint values were assigned when appropriate. The categorical data were back transformed into percent leaf area scabbed and analyzed for significance using the mixed procedure of SAS 9.2 (SAS Institute, Cary, NC). The model statement included isolate, application timing, and cultivar as fixed effects, with tree (replicate) as the random variable. A Tukey-Kramer test was conducted $(\alpha=0.05)$ to compare interaction means and determine whether bacteria were able to significantly reduce disease severity at each sampling date.

Effect of bacterial applications on fruit disease severity. All fruit were harvested from all tagged branches from 'Golden Delicious' and 'Rome Beauty' trees on 25 September and 28 October, respectively, in 2008 and on 1 September and 6 October 2009. Following harvest, fruit were evaluated for incidence and severity of apple scab. Apple scab severity on fruit was estimated using a 0 to-6 rating scale based on a visual key. Fruit were assigned a value based on the corresponding picture it most clearly resembled (Fig. 2). Fruit severity data were analyzed for significance using the Kruskal-Wallis test of SAS 9.2 (SAS Institute).

Effects of bacteria application on bitter rot severity. Marketable fruit (rated as scores of 0 or 1 based on the rating scale; Fig. 2) from each treatment were selected for use in the postharvest phase of the experiment. Four bacterial isolates were evaluated in 2008 (A1-1, A3-6, FLS-5, and A3-F1) and three in 2009 (A1-1, A3-6, and FLS-5). To determine the effects of bacterial application schedule on postharvest disease suppression, eight treatments were tested as described in Table 1. Treatments 1 and 2 received preharvest applications of the bacteria (May or May + June), treatment 3 was the untreated control, treatments 4 and 7 received only a postharvest application of bacteria, and treatments 5 and 6 received both pre and postharvest applications of the bacteria. Treatments 1 to 6 were challenged with the bitter rot pathogen, $C$. acutatum. Treatments 7 and 8 were not challenged with the pathogen and served as bacteria and wound controls.

'Golden Delicious' and 'Rome Beauty' fruit were challenged with $C$. acutatum in separate experiments. Experiments conducted on 'Golden Delicious' consisted of 10 replicate fruit in 2008 and 21 replicate fruit in 2009. Experiments conducted on 'Rome Beauty' consisted of 10 replicate fruit in 2008 and 20 replicate fruit in 2009. All fruit were wounded to a depth of $4 \mathrm{~mm}$ using a sterilized six-pence nail to simulate stem punctures. Nails were mounted through a rubber stopper to ensure uniformity of wound depth. Wounds on fruit receiving postharvest application of bacteria

Table 1. Treatments used to determine the effects of bacterial application schedules on bitter rot disease severity

\begin{tabular}{llc}
\hline Treatment & Bacterial application $^{\mathbf{a}}$ & Challenge $^{\mathbf{b}}$ \\
\hline 1 & May & + \\
2 & May + June & + \\
3 & Nontreated & + \\
4 & Postharvest & + \\
5 & May + postharvest & + \\
6 & May + June + postharvest & + \\
7 & Postharvest & - \\
8 & Nontreated & - \\
\hline
\end{tabular}

a Biocontrol bacteria were applied to 'Golden Delicious' and 'Rome Beauty' branches on 10 May and 18 June 2008 and 7 May and 19 June 2009.

b Treatments 1 to 6 were challenged with the bitter rot pathogen $\mathrm{Col}$ letotrichum acutatum (+). Treatments 7 and 8 were not challenged and served as the bacteria and wound controls $(-)$. 
(treatments 4 to 7) were inoculated with $20 \mu \mathrm{l}$ of the respective bacterial isolate at a concentration of $10^{7} \mathrm{CFU} / \mathrm{ml}\left(2.0 \times 10^{5}\right.$ CFU/wound). One hour after bacterial application, wounds were challenge inoculated with $20 \mu \mathrm{l}$ of a $4.0 \times 10^{4}$ conidia $/ \mathrm{ml}$ spore suspension of $C$. acutatum. For treatments 1 to 3 (not receiving a postharvest application of the biocontrol bacteria), wounds were challenged with $C$. acutatum as described for treatments 4 to 7 . Pathogen inoculum was prepared by flooding a 10-day-old culture of $C$. acutatum on potato dextrose agar with $10 \mathrm{ml}$ of sterile deionized water. The solution was filtered through four layers of sterile cheesecloth and the concentration adjusted to $4.0 \times 10^{4}$ conidia $/ \mathrm{ml}$ with a hemacytometer (American Optical, Buffalo, NY). Once the
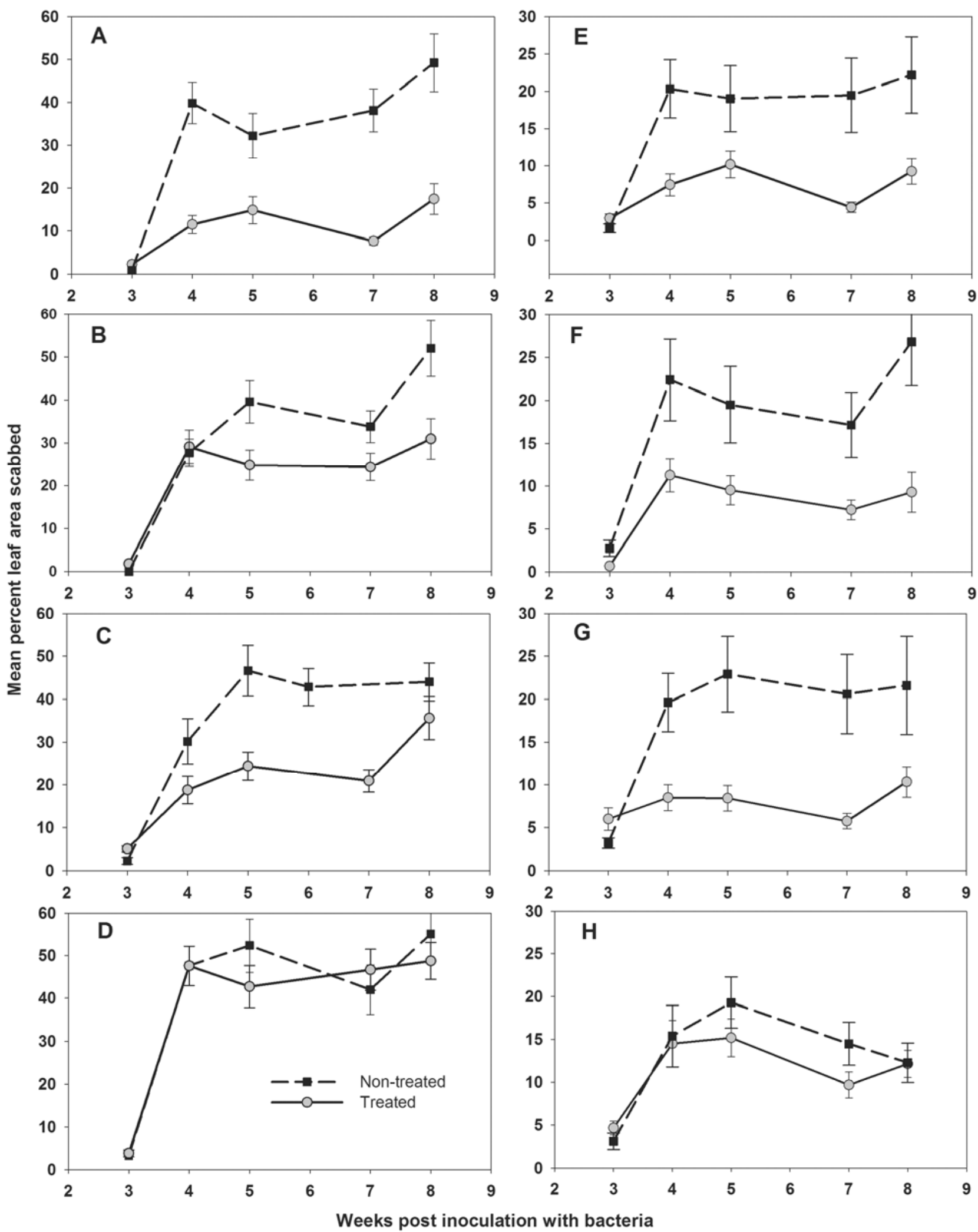

Fig. 3. Mean percent leaf area with apple scab symptoms on A-D, 'Golden Delicious' and E-H, 'Rome Beauty' in 2008. Bacterial treatments A and E, A1-1; B and F, A3-6; C and G, FLS-5; and D and H, A3-F1 were applied on 10 May and 18 June 2008. Nontreated controls were treated with $0.1 \%$ Silwet L-77. Leaves on 32 shoots per tree were evaluated for apple scab severity 3 through 8 weeks post application of the bacteria. Error bars represent the standard error of the mean. 
pathogen inoculum droplets applied to the wounds dried, the fruit were arranged on 20-count molded cardboard trays in 2008, with each tray consisting of two replicate fruit of each treatment. In 2009 , fruit were placed in 20-count molded plastic trays with plastic covers, which were drilled to produce five holes in the plastic covers to allow for air exchange. In both years, the trays were stored in a dark walk-in growth room at $20^{\circ} \mathrm{C}$ on shelves. Fruit were evaluated daily for symptom severity 3 to 8 days post inoculation (dpi). To assess disease severity, the lesion diameter was measured laterally and horizontally across the wound site and the total lesion area was estimated using the average of the two measurements. Data were analyzed for significance using SAS mixed-model repeated measures with the Toepltiz covariance structure. The statistical model contained bacterial isolate, application schedule, days post inoculation, and the interaction term bacterial isolate-application schedule. For each isolate, single degree-offreedom contrasts were used to partition treatment sums of squares to compare specific application treatments or groups of treatments as well as interactions of interest. A Tukey-Kramer test $(\alpha=0.05)$ was also used to used to separate means.

\section{Results}

Effect of bacterial application on foliar disease severity. Overall, apple scab pressure was high in the FREC experimental orchard in 2008 (incidence $>96 \%$ on 13 June on nontreated leaves). A severe risk of infection persisted during the primary scab period from 15 March to 15 June, in which 8 severe infection periods and 10 moderate infection events were recorded. Rainfall for April through August 2008 was 126.2, 160, 63.2, 95.8, and $62 \mathrm{~mm}$, respectively. Apple scab pressure was also high in 2009 (incidence $>98 \%$ on 8 June on nontreated leaves) and several infection periods occurred during the primary period from 16 March to 15 June. Specifically, there were six moderate infection events that occurred over 11 days and included one to four continuous days of wetting and 9 severe infection events that included two to five continuous days of wetting. Rainfall for April though August 2009 was 111.8, $175.3,112.3,126.5$, and $70 \mathrm{~mm}$, respectively.

In 2009, isolates FLS-5 and A3-6 colonized apple foliage in the field. Differences in colonization on Golden Delicious and Rome Beauty were not statistically significant and; therefore, the data were pooled $(P>0.05)$. Isolate FLS-5 had the highest populations both 1 and 7 weeks post inoculation, ranging from $\log 4.4$ to $\log$ $3.5 \mathrm{CFU} / \mathrm{cm}^{2}$. Populations of isolate A3-6 averaged $\log 2.4$ $\mathrm{CFU} / \mathrm{cm}^{2} 1$ week post inoculation and $\log 1.6 \mathrm{CFU} / \mathrm{cm}^{2} 7$ weeks post inoculation. Isolate A1-1 remained below detectable levels throughout the sampling period.

The May application treatment versus the May + June application treatment were not significantly different with regards to foliar apple scab severity in $2008(P>0.16)$ and $2009(P>0.22)$; therefore, these data were combined for statistical analyses. In the 2008 study, treating leaves with isolates A1-1 and FLS-5 significantly $(P$ $<0.05)$ reduced foliar apple scab severity on 'Golden Delicious' and 'Rome Beauty' from 4 weeks (6 June) post application of the bacteria through 8 weeks (16 July) compared with nontreated leaves (Fig. 3). Isolate A3-6 significantly reduced foliar apple scab severity in weeks 4 to 8 on 'Rome Beauty' $(P<0.01)$ but was not significantly different from the control until week 5 on 'Golden Delicious'. Treating leaves with isolate A1-1 reduced mean leaf area with scab symptoms by 65 and $58 \%$ on 'Golden Delicious' and 'Rome Beauty', respectively, compared with control leaves at the end of the experiment ( 8 weeks post inoculation of the bacteria). Treating leaves with isolate A3-6 reduced mean leaf area with apple scab symptoms by 41 and $65 \%$ on 'Golden Delicious' and 'Rome Beauty' leaves, respectively, compared with control leaves at the end of the experiment. Isolate A3-F1 did not significantly reduce disease severity on either cultivar tested in $2008(P>0.96)$. As a result isolate A3-F1 was not included in the 2009 experiment.

In 2009, treating leaves with any of the three isolates tested (A1-1, A3-6, and FLS-5) significantly $(P<0.05)$ reduced foliar apple scab severity compared with the nontreated control from 3 to 8 weeks post inoculation with the bacteria (Fig. 4). Most likely due to the addition of a sulfur program (as a treatment applied to all test trees) in 2009 , the overall mean percent area with scab symptoms on all treatments was lower in 2009 compared with 2008. At 8 weeks post inoculation ( 2 weeks after the second application), leaves treated with isolate A1-1 averaged $13.7 \%$ leaf area with apple scab symptoms on 'Rome Beauty' compared with $25.2 \%$ on control leaves, representing a $45 \%$ reduction in disease severity. Application of isolate A3-6 on 'Rome Beauty' leaves resulted in a $42 \%$ reduction in severity compared with the control. On 'Golden Delicious', isolates A1-1 and A3-6 resulted in a 48 and $45 \%$ reduction respectively, in mean percent leaf area with apple scab symptoms.

Effect of bacterial application on apple scab severity on fruit. Fruit harvested from branches treated with isolates A1-1 and FLS-5 in 2008 had significantly lower apple scab severity on 'Golden Delicious' $(P<0.001)$ and 'Rome Beauty' $(P<0.01)$ compared with fruit harvested from nontreated branches (Fig. 5). Treating branches in May with isolate A3-6 reduced apple scab severity on 'Golden Delicious' fruit $(P<0.03)$ but not on 'Rome Beauty' fruit $(P=0.14)$ in the 2008 study. Mean fruit apple scab incidence on the no-bacteria control fruit was $97 \%$ on 'Golden Delicious' and 93\% on 'Rome Beauty' in 2008. Fruit harvested from branches treated with isolate A1-1 had the lowest apple scab incidence on 'Golden Delicious': 76 and 64\% from the May and May + June treatments respectively.

In 2009, treating branches with isolates A1-1 and A3-6 significantly reduced mean apple scab severity on fruit compared with control fruit of 'Golden Delicious' $(P<0.01)$ and 'Rome Beauty'

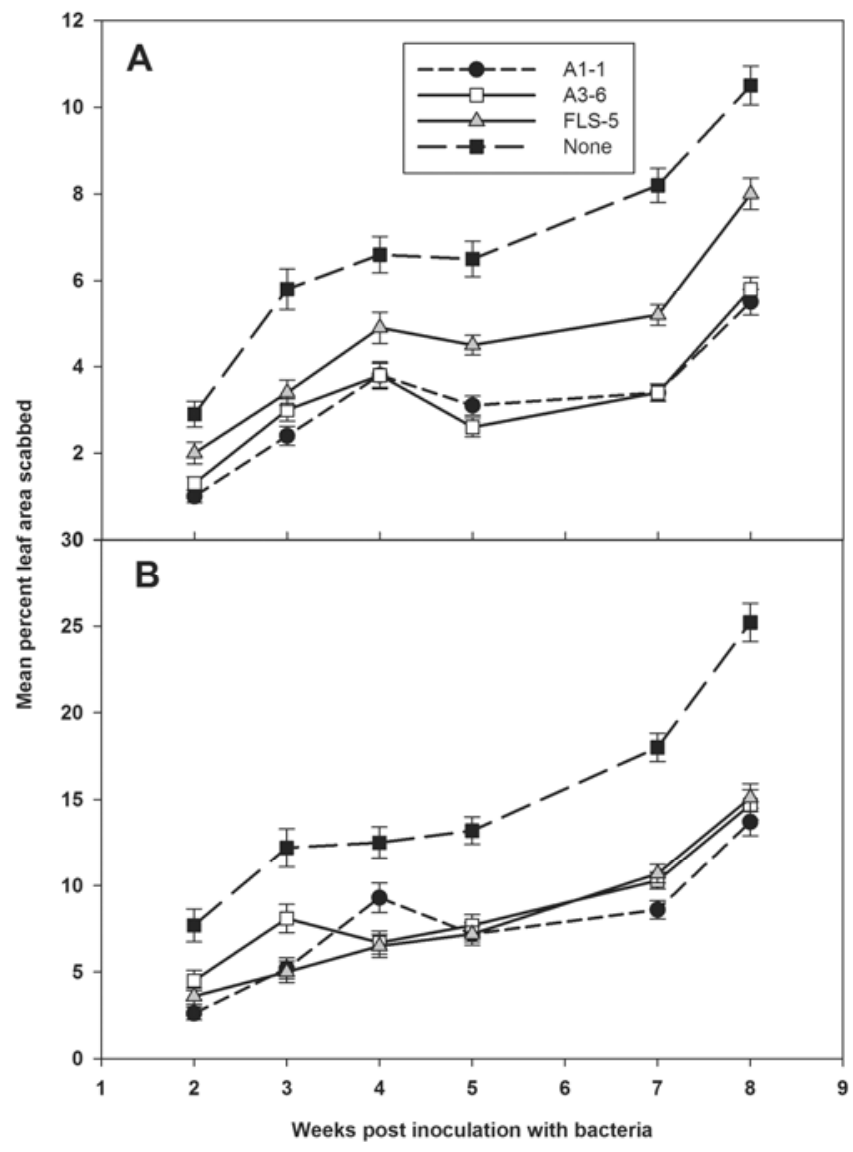

Fig. 4. Mean percent leaf area with apple scab symptoms on A, 'Golden Delicious' and B, 'Rome Beauty' at the Fruit Research and Extension Center in 2009. Bacterial treatments were applied on 7 May and 19 June 2009 (6 weeks post inoculation). Control trees were treated with $0.1 \%$ Silwet L-77. Leaves of 64 shoots per tree were evaluated weekly for apple scab severity from 3 to 8 weeks post inoculation of the bacteria. Error bars represent the standard error of the mean. 
$(P<0.003)$ (Fig. 6). Fruit harvested from branches treated with isolate FLS-5 had significantly lower scab severity on 'Golden Delicious' $(P<0.03)$ but not on 'Rome Beauty' $(P>0.08)$. Mean apple scab incidence on fruit in 2009 was 87 and $96 \%$ on nobacteria control 'Golden Delicious' and 'Rome Beauty' fruit, respectively. As observed in 2008, fruit harvested from branches treated with isolate A1-1 had the lowest incidence of apple scab: 53 and $63 \%$ from the May and May + June treatments, respectively, on Golden Delicious fruit in 2009.

Effect of bacterial application on suppression of bitter rot. In 2008, few Rome Beauty fruit (most noticeably in control treatments) were suitable for use in the postharvest phase of the experiment due to severe scab infection. There were no significant differences in mean lesion size on 'Rome Beauty' fruit in 2008. Statistical analysis indicated a significant interaction between bacteria and application schedule $(P<0.001)$ on 'Golden Delicious' fruit harvested in 2008. Single degree-of-freedom contrasts indicated that the effect of adding a postharvest application of bacteria to either the May or May + June application treatments was similar for all isolates $(P>0.07)$. Lesions on 'Golden Delicious' fruit receiving a postharvest application of isolates A1-1, A3-6, and FLS-5 were significantly $(P<0.04)$ smaller compared with lesions on control fruit in 2008 (Fig. 7). Fruit receiving the May + postharvest ap- plication of isolate A3-6 resulted in lesions that were 48\% smaller than lesions on control fruit, whereas fruit receiving only a postharvest application of bacteria resulted in a $28 \%$ reduction compared with untreated controls at $8 \mathrm{dpi}$. The combined application of isolate A3-6 May + postharvest also resulted in smaller lesion size at the end of the experiment ( $8 \mathrm{dpi}$ ) compared with the postharvest application alone $(P=0.008)$. Fruit receiving a postharvest application of isolate A1-1 or A3-6 did not develop symptoms until 6 dpi whereas nontreated control fruit typically developed symptoms 5 days after treatment, indicating a 1-day delay in the onset of symptom development. There was no statistically significant difference between treatments combining a preharvest and postharvest application of bacteria compared with the postharvest alone treatment for isolates A1-1, A3-F1, or FLS-5 over the 8-day sampling period $(P>0.3)$. There were also no significant differences in lesion size on 'Golden Delicious' fruit harvested from branches treated preharvest with isolates A1-1, A3-6, or A3-F1 (not receiving a postharvest application of bacteria) compared with the nontreated control lesions in the 2008 study year.

In 2009, a postharvest application of all three of the tested isolates resulted in significantly $(P<0.001)$ smaller bitter rot lesion area compared with the no-bacteria controls on 'Rome Beauty' and 'Golden Delicious' fruit (Fig. 8). Statistical analysis indicated a

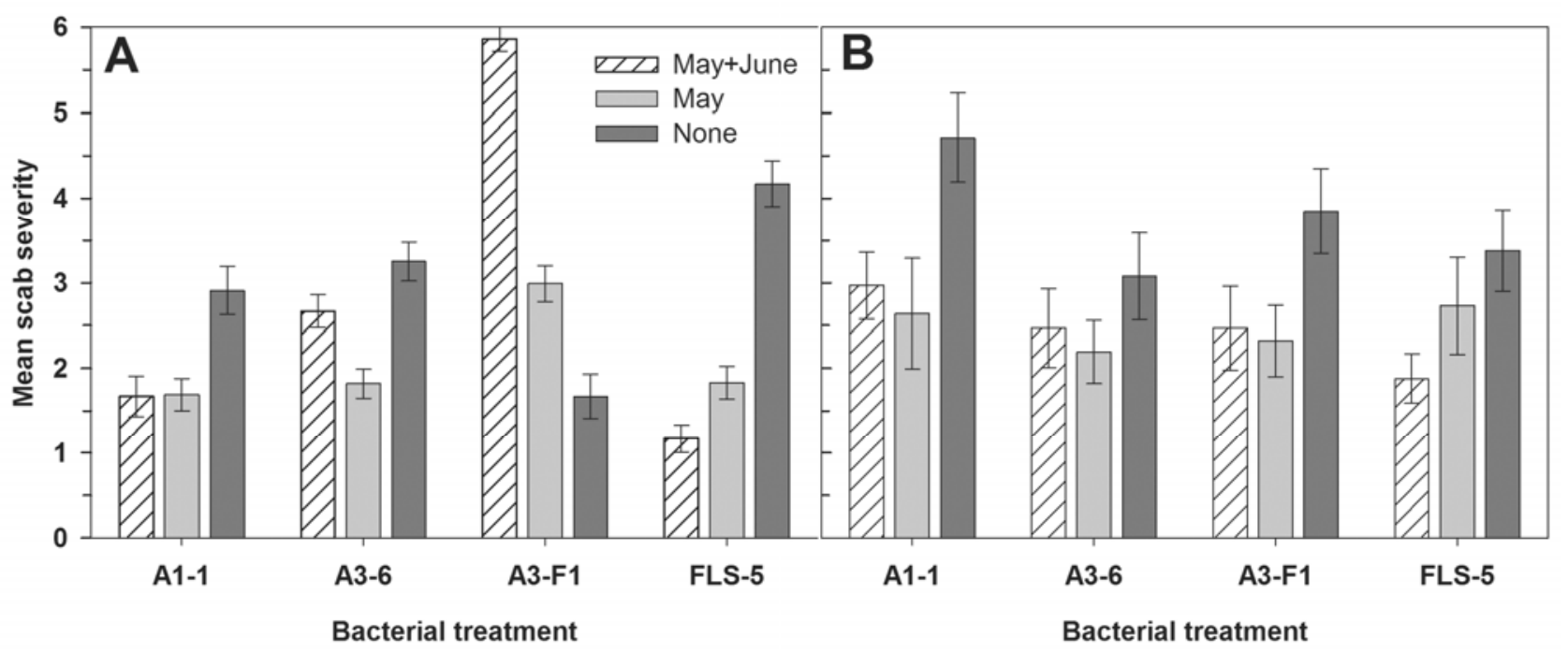

Fig. 5. Apple scab severity on A, 'Golden Delicious' and B, 'Rome Beauty' fruit in 2008. Fruit were harvested from branches sprayed with bacteria on 10 May (May) or 10 May + 19 June (May + June), or nontreated (None). Apple scab severity was evaluated using a 0-to-6 visual scale. Data were analyzed for significance using the Kruskal-Wallis test.

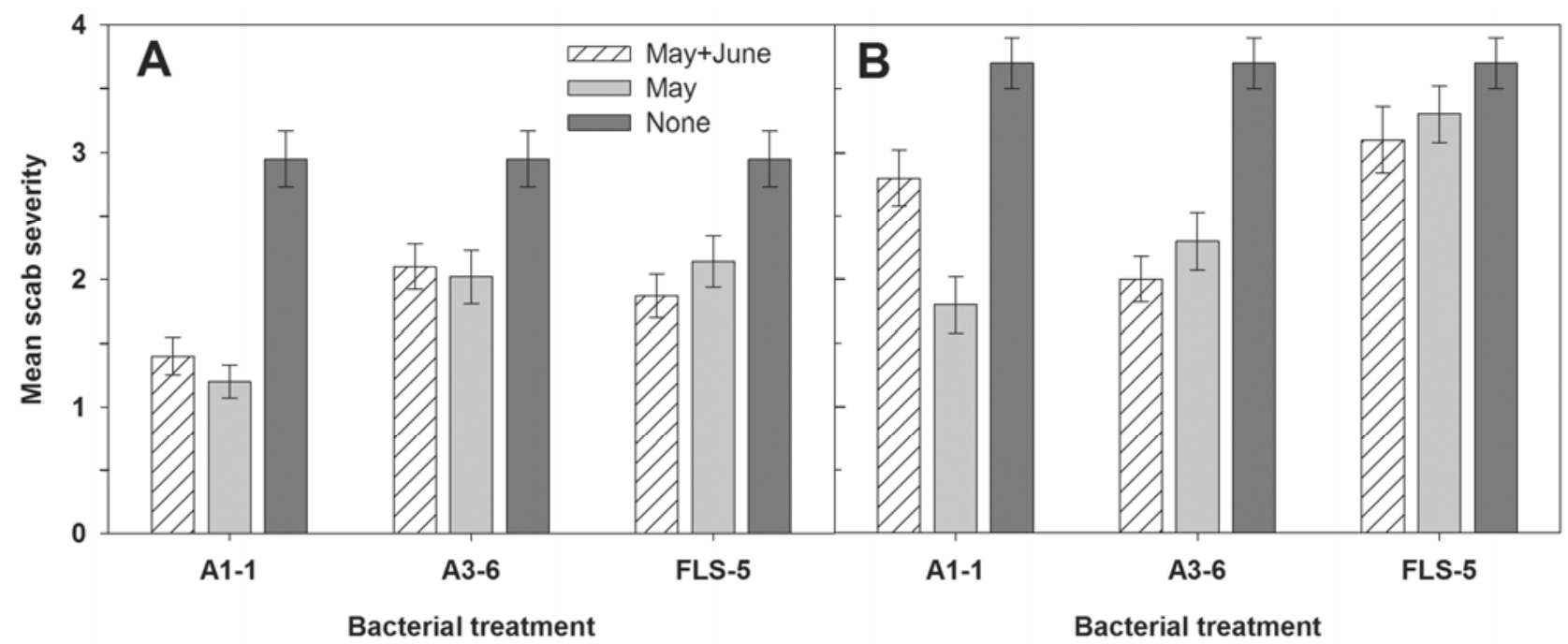

Fig. 6. Apple scab severity on A, 'Golden Delicious' and B, 'Rome Beauty' fruit in 2009. Fruit were harvested from branches sprayed with bacteria on 10 May (May) or 10 May + 19 June (May + June), or not treated (None). Apple scab severity was evaluated using a 0-to-6 visual scale. Data were analyzed for significance using the Kruskal-Wallis test. 
significant effect of bacterial isolate $(P<0.0001)$, application schedule $(P<0.02)$, and a bacterial isolate-application schedule interaction on both cultivars tested $(P<0.0008)$. Preharvest applications in May or May + June (without an additional postharvest application) of isolates A1-1 and FLS-5 resulted in a significantly $(P<0.0001)$ smaller bitter rot lesion area on 'Rome Beauty' fruit whereas only the May + June application of isolate A3-6 was significant $(P<0.0001)$. On 'Golden Delicious' fruit, the May or May + June preharvest application of isolates A1-1 and FLS-5 resulted in significantly smaller $(P<0.0001)$ bitter rot lesion size compared with lesions on the no-bacteria control fruit. Single degree-of-freedom contrasts indicated that there was a similar effect of adding a postharvest application to either the May or May + June application schedules for isolates A1-1 and FLS-5 $(P>0.3)$ on 'Rome Beauty' fruit. On 'Golden Delicious' fruit, the effect of adding a postharvest application (to the May or the May + June schedule) was similar for isolates A3-6 and A1-1. In general, a postharvest application (alone or in combination with a preharvest application) resulted in the greatest suppression of bitter rot lesion size on both cultivars. A postharvest application of isolates A3-6 and FLS-5 provided a significantly greater reduction in bitter rot lesion size compared with preharvest applications on 'Rome Beauty' $(P<0.001)$ and 'Golden Delicious' $(P<0.04)$. A postharvest application of isolate A1-1, however, improved the level of suppression from the preharvest application on 'Rome Beauty' $(P<0.0001)$ but not on 'Golden Delicious' fruit $(P=0.14)$. Overall, application of isolate A3-6 resulted in the smallest bitter rot lesion areas in 2009. Fruit receiving a May + June + postharvest application of isolate A3-6 resulted in a 41 and $95 \%$ reduction in lesion area on 'Golden
Delicious' and 'Rome Beauty', respectively, compared with the no-bacteria control.

\section{Discussion}

Our study has demonstrated that preharvest application of $B$. megaterium isolate A3-6, B. mycoides isolate A1-1, or B. cereus isolate FLS-5 followed by a second postharvest application can simultaneously suppress apple scab on leaves and fruit and also suppress bitter rot on fruit in storage. To the best of our knowledge, this study is the first report of the evaluation of endospore-forming bacteria for biological control of pre- and postharvest diseases of apple when applied as preharvest treatments. Furthermore, studies evaluating preharvest applications of BCAs on apple for postharvest disease suppression have generally tested late-season applications ranging from 4 weeks to 2 days before harvest $(18,20,24)$. Our review of the literature indicated no studies on suppression of the preharvest disease apple scab by BCAs in combination with suppression of postharvest diseases on apple.

Our study has also demonstrated the potential for combining the tested BCAs with sulfur and copper. Application of the bacterial isolates A1-1, A3-6, and FLS-5 alone reduced foliar and fruit apple scab disease severity as well as when combined with a sulfur/copper spray program compared with the sulfur/copper control. Isolates A1-1 and A3-6 provided the greatest reduction in foliar and fruit scab in both years of study. However, isolate A1-1 demonstrated poor field colonization of 'Golden Delicious' and 'Rome Beauty' leaves compared with isolates FLS-5 and A3-F1, suggesting that higher population levels may not be required for scab suppression by this isolate, or that the method of suppression is independent of population size. Season-long suppression of scab
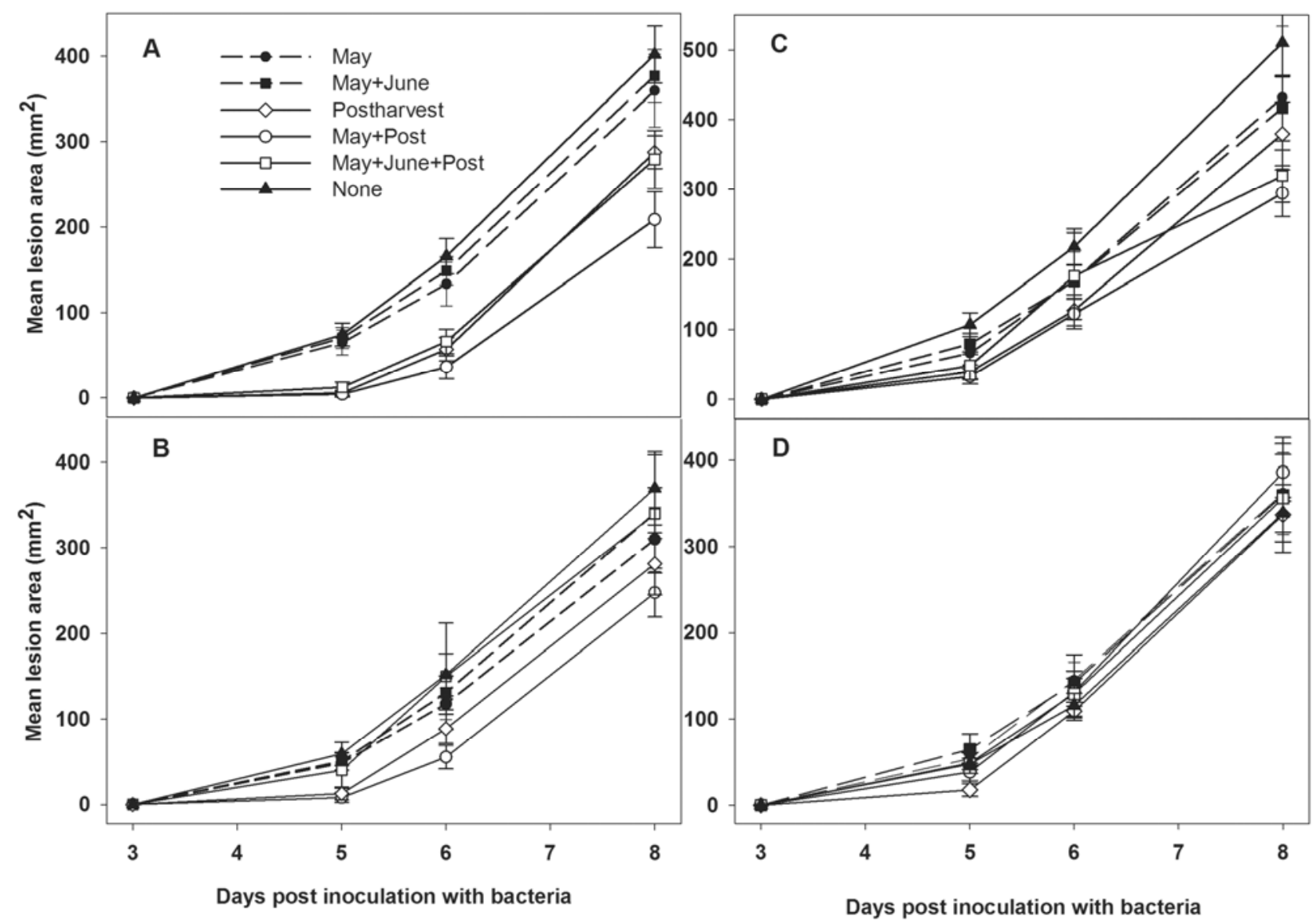

Fig. 7. Mean lesion area $\left(\mathrm{mm}^{2}\right)$ on 'Golden Delicious' fruit wound inoculated postharvest with Colletotrichum acutatum in 2008. Four bacterial isolates were tested: A, A3-6; B, A1-1; C, FLS-5; and D, A3-F1. Fruit were harvested from nontreated branches and branches treated with bacterial isolates on 10 May (May) and 10 May and 19 June (May + June). After harvest, fruit were wounded and bacteria were added to wounds of fruit not treated in the field (Postharvest) or those treated in May (May + Post), or May and June (May + June + Post). The control treatment (none) represents fruit that did not receive bacteria in the field or postharvest. Data were analyzed using the SAS mixedrepeated-measures model. 
severity was observed on both directly sprayed and newly emerged, nonsprayed leaves on the same shoot. It is possible that application of isolate A1-1 resulted in activation of plant defenses in the new growth, and this induced resistance may have suppressed the eliciting organism as well as the pathogen. Activation of plant defense proteins by nonpathogenic organisms has been demonstrated in apple $(16,17)$.

When applied postharvest, isolates A1-1, A3-6, and FLS-5 resulted in a significant reduction in mean lesion area of bitter rot incited by $C$. acutatum on Golden Delicious and Rome Beauty fruit compared with lesions on nontreated fruit. These results were observed on fruit harvested from trees receiving a reduced spray program and unmanaged trees. For all isolates tested, a preharvest application did not suppress lesions incited by $C$. acutatum in fruit wounds compared with suppression achieved with a postharvest application of the bacteria. Furthermore, the combination of preharvest and postharvest applications of bacteria did not provide additional benefits over the single postharvest application with regards to bitter rot suppression in wounds. A similar result was reported by Teixido et al. (31) in a study comparing biocontrol efficacy of preharvest and postharvest applications of Candida sake to wounded apples inoculated with $P$. expansum. Preharvest applications ( 2 days before harvest) of yeast cells provided significant control; however, maximum control was achieved with postharvest application. Teixido et al. (31) also reported no advantage in combining pre- and postharvest application of the yeast antago-
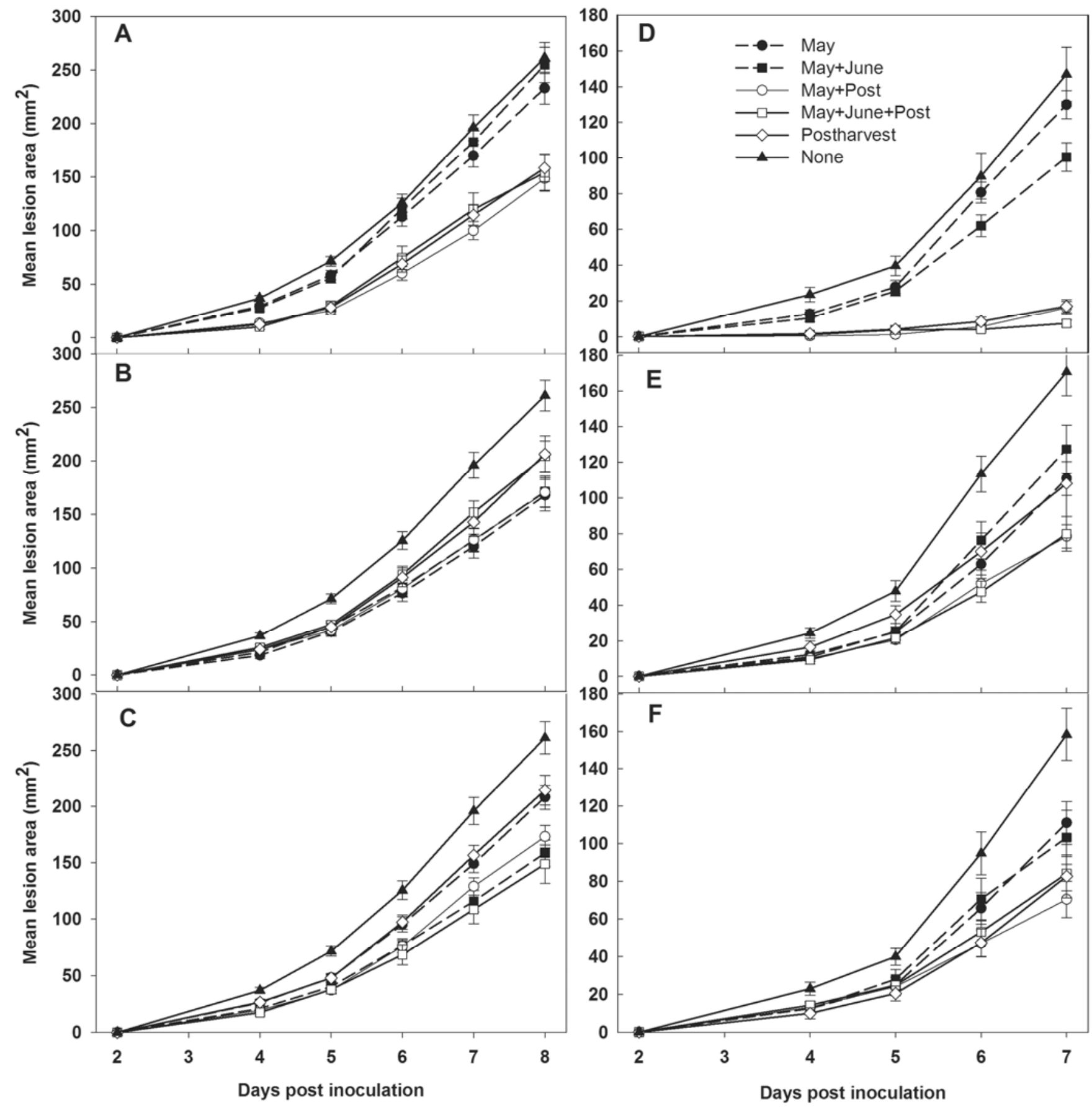

Fig. 8. Mean lesion area $\left(\mathrm{mm}^{2}\right)$ on A-C, 'Golden Delicious' and D-F, 'Rome Beauty' fruit inoculated with Colletotrichum acutatum in 2009. Three bacterial isolates were tested: A and D, A3-6; B and E, A1-1; and C and F, FLS-5. Fruit were harvested from nontreated branches and branches treated on 7 May (May) and 7 May and 18 June 2009 (May + June). After harvest, fruit were wounded and bacteria were added to wounds of fruit not treated in the field (Postharvest) or those treated in May (May + Post), or May and June (May + June + Post). The control treatment (none) represents fruit that did not receive bacteria in the field or postharvest. Data were analyzed using the SAS mixed-repeated-measures model. 
nist. Because the inoculum dose of $C$. acutatum in our experiments was high (approximately 800 conidia/wound), it may have overwhelmed host-induced resistance that would have been a likely mechanism active in a fresh wound on the fruit. Further experiments are needed to determine the effects of pathogen dose on disease suppression by pre- and postharvest applied bacteria. The postharvest phase of this study was also conducted at room temperature. Although it is promising to achieve disease suppression at temperatures that promote rapid growth of the pathogen and fruit ripening, future studies are needed to determine the level of disease suppression under commercial cold storage conditions $\left(1^{\circ} \mathrm{C}\right.$ and $21 \% \mathrm{O}_{2}$ ). Elevated levels of carbon dioxide and decreased levels of oxygen in controlled- or modified-atmosphere storage facilities are used in conjunction with refrigeration to extend the storage life of fresh produce. Future studies are needed to determine colonization of fruit and postharvest disease suppression by our Bacillus isolates under these storage conditions. Improvement in postharvest disease suppression by BCAs has been reported in other studies. For example, Usall et al. (32) reported that $C$. sake increased or retained effectiveness in controlling $P$. expansum in controlledatmosphere storage compared with traditional storage.

Although a synergistic effect was not observed in our study for treatments combining pre- and postharvest application strategies, there is an additive effect in that preharvest applications of biocontrol bacteria were able to reduce foliar and fruit scab, and additional postharvest applications were effective in reducing bitter rot severity. Although application of a single organism to control both pre- and postharvest disease has not been previously reported for apple, application of organisms has proven successful in other systems. For example, preharvest applications of $B$. licheniformis to mango trees have proven effective in controlling both pre- and postharvest diseases, including bacterial black spot (Xanthomonas campestris pv. magiferaeindicae) and soft rot (29). Preharvest sprays of $B$. subtilis on avocado have been reported effective for control of the preharvest diseases black spot (Pseudocercospora purpurea) and sooty blotch (Akaropeltopsis sp.) and postharvest decay from anthracnose, stem-end, rot and the DothiorellaColletotrichum fruit rot complex $(14,15)$.

A majority of the published experiments report preharvest and postharvest disease data as incidence (percent leaves or fruit infected). In the current study, the severities of apple scab and bitter rot symptoms were evaluated to determine the effectiveness of the bacterial isolates as biocontrols. Severity data is more informative because the incidence of apple scab on leaves may be very similar among treatments; however, there is a considerable difference between (for example) 5 and 50\% leaf area scabbed. Biological control rarely results in $100 \%$ disease control; thus, incidence data may not reveal significant differences. Successful BCAs often reduce disease severity below an acceptable threshold, delay the onset of symptoms, or decrease the rate of disease spread. BCAs may also allow for disease control when combined with reduced rates of fungicides $(2,23)$.

The achievement of successful biological control (of plant pests or pathogens) depends not only on the biocontrol agent itself but also on the application of the agent or agents when and where they are needed to maximize control (5). Our study demonstrated that two field applications of Bacillus BCAs were able to reduce fruit and foliar scab severity on apple. Further research is needed to optimize the biocontrol efficacy of our isolates. Additional experiments that would focus on the rate of bacterial application, timing, number of applications, and survival and redistribution of bacteria after application could all lead to more predictable benefits from treatment. Because biological control systems often fail to provide sufficient control on their own, an integrated approach offers a more reliable strategy for disease control. Implementation into an integrated pest management program combining multiple strategies such as sanitation, host resistance, reduced rates of fungicides, and biocontrols may provide for a more effective use of a BCA. For successful integration, it is important to identify BCAs that are able to survive and reduce disease when combined with commonly used fungicides and insecticides. More information is needed on the colonization of our biocontrol isolates in the field and in storage, particularly when integrated into existing apple management programs.

\section{Acknowledgments}

This project was supported by the Penn State Department of Plant Pathology, the United States Agency for International Development SANREM CRSP, and the generous support of the American people through Cooperative Agreement number EPP-A-00-04-00013-00. We thank the faculty and staff at the FREC, including J. Travis, N. Halbrendt, and B. Lehman, for their assistance and advice; and R. Melnick, M. del Mar Jimenez-Gasco, and T. McNellis for reviewing drafts of this manuscript.

\section{Literature Cited}

1. Benbow, J. M., and Sugar, D. 1999. Fruit surface colonization and biological control of postharvest diseases of pear by preharvest yeast applications Plant Dis. 83:839-844.

2. Buck, J. W. 2004. Combinations of fungicides with phylloplane yeasts for improved control of Botrytis cinerea on geranium seedlings. Phytopathology 94:196-202.

3. Cañamás, T. P., Viñas, I., Torres, R., Usall, J., Solsona, C., and Teixidó, N. 2011. Field applications of improved formulations of Candida sake CPA-1 for control of Botrytis cinerea in grapes. Biol. Control 56:150-158.

4. Castoria, R., and Wright, S. A. I. 2010. Host responses to biological control agents. Pages 171-181. in: Postharvest Pathology, Plant Pathology in the 21 st Century. D. Prusky, and M. L. Gullino, eds. Springer Science+Business Media, Dordrecht, The Netherlands.

5. Cook, R. J. 1993. Making greater use of introduced microorganisms for biological control of plant pathogens. Annu. Rev. Phytopathol. 31:53-80.

6. Croxall, H. E., Gwynne, D. C., and Jenkins, E. E. 1952. The rapid assessment of apple scab on leaves. Plant Pathol. 1:39-41.

7. Droby, S., Wisniewski, M., and Wilson, C. 2003. Biological control of postharvest diseases of fruits and vegetables: Current achievements and future challenges. Acta Hortic. 628:703-713.

8. Eckert, J. W., and Ratnayake, M. 1983. Host-pathogen interactions in postharvest diseases. Pages 247. in: Post-harvest Physiology and Crop Preservation. M. Lieberman, ed. Plenum Press, New York.

9. Emmert, E. A. B., and Handelsman, J. 1999. Biocontrol of plant disease: a (gram-) positive perspective. FEMS Microbiol. Lett. 171:1-9.

10. Errampalli, D., and Brubacher, N. R. 2006. Biological and integrated control of postharvest blue mold (Penicillium expansum) of apples by Pseudomonas syringae and cyprodinil. Biol. Control 36:49-56.

11. Janisiewicz, W. J. 2010. Quo vadis of biological control of postharvest diseases. Pages 137-148 in: Postharvest Pathology. D. Prusky, and M. L. Gullino, eds. Springer, Dordrecht, The Netherlands.

12. Janisiewicz, W. J., and Korsten, L. 2002. Biological control of postharvest diseases of fruits. Annu. Rev. Phytopathol. 40:411-441.

13. Kokalis-Burelle, N., Backman, P. A., Rodriguez-Kabana, R., and Ploper, L. D. 1992. Potential for biological control of early leafspot of peanut using Bacillus cereus and chitin as foliar amendments. Biol. Control 2:321-328.

14. Korsten, L., De Villiers, E. E., Duvenhage, J. A., and Kotze, J. M. 1994 Control of avocado preharvest diseases with Bacillus subtilis and fungicide sprays. S. Afr. Avocado Grow. Assoc. Yearb. 17:32-34.

15. Korsten, L., De Villiers, E. E., Wehner, F. C., and Kotze, J. M. 1997. Field sprays of Bacillus subtilis and fungicides for control of preharvest fruit diseases of avocado in South Africa. Plant Dis. 81:455-459.

16. Kürkcüoglu, S., Piotrowski, M., and Gau, A. 2004. Up-regulation of pathogenesis-related proteins in the apoplast of Malus domestica after application of a non-pathogenic bacterium. J. Biosci. 59c:843-848.

17. Kürkcüoglu, S., Degenhardt, J., Lensing, J., Al-Masri, A. N., and Gau, A. E. 2007. Identification of differentially expressed genes in Malus domestica after application of the non-pathogenic bacterium Pseudomonas fluorescens Bk3 to the phyllosphere. J. Exp. Bot. 58:733-741.

18. Lahlali, R., Massart, S., De Clercq, D., Serrhini, M., Creemers, P., and Jijakli, M. 2009. Assessment of Pichia anomala (strain K) efficacy against blue mould of apples when applied pre- or post-harvest under laboratory conditions and in orchard trials. Eur. J. Plant Pathol. 123:37-45.

19. Lee, S. A., Ngugi, H. K., Halbrendt, N. O., O'Keefe, G., Lehman, B., Travis, J. W., Sinn, J. P., and McNellis, T. W. 2010. Virulence characteristics accounting for fire blight disease severity in apple trees and seedlings. Phytopathology 100:539-550.

20. Leibinger, W., Breuker, B., Hahn, M., and Mendgen, K. 1997. Control of postharvest pathogens and colonization of the apple surface by antagonistic microorganisms in the field. Phytopathology 87:1103-1110.

21. MacHardy, W. E. 1996. Apple Scab: Biology, Epidemiology and Management. American Phytopathological Society Press, St. Paul, MN.

22. MacHardy, W. E., and Gadoury, D. M. 1989. A revision of Mill's criteria for predicting apple scab infection periods. Phytopathology 79:304-310.

23. Neher, O. T., M. R. Johnston, N. K. Zidack, and B. J. Jacobsen. 2009. Evaluation of Bacillus mycoides isolate $\mathrm{BmJ}$ and B. mojavensis isolate 2037 for the control of anthracnose of cucurbits caused by Glomerella cingulata var. orbiculare. Biol. Control 48:140-146. 
24. Nunes, C., Usall, J., Teixidó, N., Abadias, M., and Viñas, I. 2007. Preharvest application of a combined treatment of Candida sake (CPA-1) and Pseudomonas syringae (CPA-5) to control postharvest decay of pome fruits. IOBC WPRS Bull. 30:397-400.

25. Nunes, C., Usall, J., Teixidó, N., Fons, E., and Viñas, I. 2002. Post-harvest biological control by Pantoea agglomerans (CPA-2) on Golden Delicious apples. J. Appl. Microbiol. 92:247-255.

26. Parker, D. M., Hilber, U. W., Bodmer, M., Smith, F. D., Yao, C., and Koller, W. 1995. Production and transformation of conidia of Venturia inaequalis. Phytopathology 85:87-91.

27. Ragsdale, N. N., and Sisler, H. D. 1994. Social and political implications of managing plant diseases with decreased availability of fungicides in the United States. Annu. Rev. Phytopathol. 32:545-557.

28. Sharma, R. R., Singh, D., and Singh, R. 2009. Biological control of postharvest diseases of fruits and vegetables by microbial antagonists: a review. Biol. Control 50:205-221.

29. Silimela, M., and Korsten, L. 2007. Evaluation of pre-harvest Bacillus licheniformis sprays to control mango fruit diseases. Crop Prot. 26:14741481.

30. Tehon, L. R., and Stout, G. L. 1930. Epidemic diseases of fruit trees in Illinois, 1922-1928. Bulletin Illinois Department of Education, Nat. Hist. Surv. 17:415-502

31. Teixidó, N., Usall, J., and Viñas, I. 1999. Efficacy of preharvest and postharvest Candida sake biocontrol treatments to prevent blue mould on apples during cold storage. Int. J. Food Microbiol. 50:203-210.

32. Usall, J., Teixidó, N., Fons, E., and Viñas, I. 2000. Biological control of blue mould on apple by a strain of Candida sake under several controlled atmosphere conditions. Int. J. Food Microbiol. 58:83-92.

33. Wisniewski, M., and Wilson, C. L. 1992. Biological control of postharvest diseases of fruits and vegetables: recent advances. HortScience 27:94-98.

34. Zhang, H., Wang, L., Ma, L., Dong, Y., Jiang, S., Xu, B., and Zheng, X 2009. Biocontrol of major postharvest pathogens on apple using Rhodotorula glutinis and its effects on postharvest quality parameters. Biol. Control 48:79-83 